\title{
PEMAHAMAN NILAI PHI (T) TERHADAP RUMUS KELILING LINGKARAN PADA MAHASISWA PGSD 2018 UNIROW TUBAN
}

\author{
Saeful Mizan \\ miz_zhan@yahoo.com \\ PGSD, FKIP, Universitas PGRI Ronggolawe Tuban
}

\begin{abstract}
Abstrak: Sebagai calon pendidik, khususnya mahasiswa Unirow Tuban diharapkan memiliki kompetesi yang memadai. Kompetensi yang dimaksud adalah terutama pengusaan materi pembelajaran matematika yang akan diajarkan kepada siswa sekolah dasar. Salah satu materi yang sering dianggap mudah namun kenyataannya banyak pendidik bahkan mahasiswa juga kesulitan dalam mengajar adalah memahamkan nilai phi $(\pi)$ dalam rumus keliling lingkaran. Hasil wawancara dengan salah mahasiswa angkatan 2018 mengemukakan bahwa mahasiwa tersebut tidak tahu asal nilai phi $(\pi)$ pada rumus keliling lingkaran, yang diingat mahasiswa ketika pembelajaran materi lingkaran terkadang dimulai dengan memberikan rumus keliling lingkaran, kemudian dilanjutkan dengan menyelesaikan contoh soal. Penelitian ini bertujuan untuk menganalisis dan mendeskripsikan pemahaman mahasiswa terhadap bilangan phi $(\pi)$ pada rumus keliling lingkaran. Jenis penelitian yang digunakan adalah deskriptif dengan pendekatan kualitatif. Subjek penelitian adalah 70 mahasiswa. Teknik pengambilan data menggunakan random sampling sejumlah 75 mahasiswa. Guna mengukur kemampuan mahasiswa dilakukan tes. Berdasarkan hasil analisis data dapat disimpulkan bahwa mahasiswa PGSD Unirow Tuban 2018 mememiliki pemahaman yang tergolong masih sangat rendah dengan nilai rata-rata yang diperoleh 58,7 dalam kategori kurang baik dengan konversi nilai $\mathrm{D}$. Sebagian besar mahasiswa kesulitan dalam memahami, tertutama pada soal Poin C dan poin D yang terkait dengan asal mula nilai phi $(\pi)$ dan bagaimana mencari nilai phi $(\pi)$ itu sendiri. Jika diprosentasekan pada soal $\mathrm{C}$, mahasiswa mampu menjawab makna nilai phi $(\pi)$ sebanyak 18,66 \% (14) mahasiswa. Sedangkan pada soal D, mahasiswa mampu menjawab cara menemukan nilai phi $(\pi)$ sebanyak $16 \%$ (12) mahasiswa
\end{abstract}

Kata kunci: phi $(\pi)$, lingkaran, mahasiswa 


\title{
Saeful, Analisis Pemahaman Bilangan Phi $(\Pi) \ldots$ \\ UNDERSTANDING VALUE PHI (П) ON CIRCUMFERENCE OF CIRCLES AT PGSD 2018 UNIROW STUDENTS
}

\begin{abstract}
As a prospective educator, especially Unirow Tuban students are expected to have adequate competition. The competence in question is primarily the mastery of mathematics learning material that will be taught to elementary school students. One of the material that is often considered easy but in fact many educators and even students also have difficulty in teaching is to understand the value of phi $(\pi)$ in the formula around the circle. An interview with one of the 2018 students revealed that the student did not know the origin of the phi $(\pi)$ value in the circle circumference formula, which students remembered when learning circle material sometimes began by giving a formula around the circle, then continued by completing the example problems. This study aims to analyze and describe students' understanding of the phi $(\pi)$ numbers in the formula around the circle. This type of research is descriptive with a qualitative approach. The research subjects were 70 students. The data collection technique used a random sampling of 75 students. In order to measure the ability of students to do the test. Based on the results of data analysis, it can be concluded that the 2018 PGSD Unirow Tuban students have an understanding that is still very low with an average score of 58.7 in the poor category with a conversion of D scores. Most students have difficulty understanding, especially in point $C$ questions. and point $D$ related to the origin of the phi $(\pi)$ value and how to find the phi $(\pi)$ value itself. If it is tested on question $C$, students are able to answer the meaning of the phi $(\pi)$ value as much as $18.66 \%$ (14) students. While in question D, students are able to answer how to find the value of phi $(\pi)$ by $16 \%$ (12) students
\end{abstract}

Keywords: phi $(\pi)$, circle, student

\section{PENDAHULUAN}

Realitas perkembangan matematika di Indonesia menunjukkan masih belum mantapnya keluaran berbagai jenjang persekolahan dalam hal pengetahuan serta penguasaan matematika (Suyitno, 2005:4). Dengan kata lain, di Indonesia kemampuan keluaran dalam hal matematika masih rendah. Hal ini juga tidak terlepas dari peran pendidik khususnya guru kelas. Kenyataan tersebut tolok ukur keberhasilan pendidikan sangat bergantung pada pendidik.

Sebagai calon pendidik, khususnya mahasiswa Unirow Tuban angkatan 2018 diharapkan memiliki kompetesi yang memadai. Kompetensi yang dimaksud adalah terutama pengusaan materi pembelajaran matematika yang akan diajarkan kepada siswa sekolah dasar. Menurut Ruseffendi (1989:39) Ilmu matematika bermanfaat dalam 
Saeful, Analisis Pemahaman Bilangan Phi (П)...

pendidikan di masyarakat baik sebagai objek langsung (fakta, kemampuan, konsep, prinsip) maupun tak langsung (berfikir kritis, logia, tekun, maupun memecahkan masah lainnya). Sehingga Ilmu matematika adalah bekal bagi siswa yang sudah lulus sekolah dasar mampu menerapkan ilmu matematika dalam kehidupan sehari-hari.

Salah satu materi yang sering dianggap mudah namun kenyataannya banyak pendidik bahkan mahasiswa juga kesulitan dalam mengajar adalah memahamkan nilai phi $(\pi)$ dalam rumus keliling lingkaran. Hasil wawancara yang dilakukan menunjukkan bahwa mahasiswa kesulitan menjelaskan asal mula nilai phi $(\pi)$ pada rumus keliling lingkaran dan jawaban yang diberikan cukup nilai phi adalah 22/7. Hal tersebut merupakan gambaran dari hasil pembelajaran yang diperoleh ketika masih duduk di bangku sekolah dasar. Mahasiswa tersebut juga mengungkapkan pembelajaran biasanya dimulai dengan memberikan rumus keliling lingkaran, kemudian dilanjutkan dengan menyelesaikan contoh soal.

Kurangnya pemahaman mahasiswa terhadap cara memperoleh pengetahuan itu sendiri mengakibatkan mahasiswa cenderung meniru gaya mengajar guru mereka ketika sewaktu masih di bangku sekolah dasar dan juga pengetahuan yang tidak diperbaharui sehingga selalu terjadi siklus kesalahan yang berulang-ulang yang dilakukan. Mahasiswa menerangkan apa yang sudah diterangkan oleh gurunya ketika masih di bangku sekolah dasar. Guna memahami materi dengan baik, mahasiswa harus menemukan sendiri prinsipprinsip dasar yang mampu mengembangkan pengetahuan bagi dirinya sendiri. Schunk (2012:324) menjelaskan bahwa pendidik diharapkan mampu membangun situasi-situasi sedemikian rupa sehingga pebelajar dapat terlibat aktif dengan materi pembelajaran melalui pengolahan-pengolahan materi dan interaksi sosial. Jadi pebelajar perlu diarahkan untuk mampu mengatur diri sendiri dan berperan aktif dalam mencari fakta-fakta khususnya yang terkait dengan keliling lingkaran.sehingga mampu melakukan generalisasi dan kesimpulan.

Sebelum menemukan rumus keliling lingkaran, tentunya pebelajar harus mengetahui dulu nilai phi $(\pi)$. Menurut Soemartono dkk (1972: 157) menjelaskan bilangan bahwa 3,14 adalah bilangan pendekatan, tetapi bilangan 3,14 adalah bilangan yang cukup dipahami untuk di sekolah dasar, bilangan yang lebih teliti yaitu 3,14159265358979323. Pendekatan lain yang biasa digunakan ialah 22/7. Sehingga dalam hal ini perlu diketahui pemahaman nilai phi $(\pi)$ dalam rumus keliling lingkaran terhadap mahasiswa PGSD unirow tuban angkatan 2018 
Saeful, Analisis Pemahaman Bilangan Phi (П)...

\section{METODE}

Jenis penelitian yang digunakan adalah deskriptif dengan pendekatan kualitatif. Menurut Bogdan dan Taylor (dalam Moleong, 2007:4) penelitian kualitatif adalah prosedur penelitian yang menghasilkan data deskriptif berupa kata-kata tertulis atau lisan dari orang dan perilaku yang diamati. Penelitian dilakukan pada bulan April 2019. Subjek penelitian adalah mahasiswa PGSD Universitas PGRI Ronggolawe Tuban angkatan 2018 Kelas A sejumlah 26 mahasiswa, kelas B sejumlah 32 mahasiswa, kelas C sejumlah 37 mahasiswa. Penentuan jumlah sampel dari jumlah populasi didasarkan dengan taraf kesalahan mencapai 5\% (Sugiyono, 2010 :87). Teknik pengambilan data menggunakan random sampling sejumlah 75 mahasiswa. Guna mengukur kemampuan mahasiswa dilakukan tes. Soal tes berbentuk pilihan ganda. Soal berisi tentang pemahaman mahasiswa terhadap keliling lingkaran dan phi $(\pi)$ sejumlah empat soal evaluasi.

Untuk selanjutnya, nilai dihitung dengan menggunakan pedoman penskoran sebagai berikut.

Skor yang dicari $(S)=$ jumlah jawaban yang benar $(B)$

$$
\text { Jumlah Soal (N) }
$$

(Arifin, 2014:229)

Setelah diperoleh nilai, kemudian nilai tersebut diberi makna ke dalam bentuk kualitatif yang dimasukkan dalam rentangan hubungan antara skala angka dengan skala huruf yang mengacu pada pendapat Arikunto (2010: 245).

Tabel 1. Hubungan antara Skala Angka dan Skala Huruf

\begin{tabular}{|c|c|c|}
\hline Rentang Angka & Huruf & Keterangan \\
\hline $80-100$ & A & Sangat Baik \\
\hline $70-79$ & B & Baik \\
\hline $60-69$ & C & Cukup Baik \\
\hline $50-59$ & D & Kurang Baik \\
\hline $0-49$ & E & Tidak baik \\
\hline
\end{tabular}

\section{HASIL}

Pemahaman mahasiswa terhadap nilai phi $(\pi)$ pada mahasiswa PGSD unirow tuban kelas angkatan 2018 sebagai berikut. 
Saeful, Analisis Pemahaman Bilangan Phi (П)...

Tabel 2. Hasil Tes Pemahaman Mahasiswa terhadap Nilai Phi $(\pi)$

\begin{tabular}{|c|c|c|c|c|c|c|c|}
\hline NO & NAMA & SOAL A & SOAL B & SOAL C & SOAL D & $\begin{array}{c}\text { JML } \\
\text { SKOR }\end{array}$ & NILAI \\
\hline 1 & AS & 1 & 1 & 0 & 0 & 2 & 50 \\
\hline 2 & ASY & 1 & 1 & 0 & 0 & 2 & 50 \\
\hline 3 & CR & 1 & 1 & 0 & 0 & 2 & 50 \\
\hline 4 & DPB & 1 & 1 & 0 & 0 & 2 & 50 \\
\hline 5 & DAM & 1 & 1 & 1 & 0 & 3 & 75 \\
\hline 6 & FAF & 1 & 1 & 1 & 0 & 3 & 75 \\
\hline 7 & HSN & 1 & 1 & 0 & 1 & 3 & 75 \\
\hline 8 & IRT & 1 & 1 & 0 & 1 & 3 & 75 \\
\hline 9 & IRP & 1 & 1 & 0 & 1 & 3 & 75 \\
\hline 10 & LI & 1 & 1 & 0 & 1 & 3 & 75 \\
\hline 11 & MI & 1 & 1 & 0 & 1 & 3 & 75 \\
\hline 12 & $\mathrm{MH}$ & 1 & 1 & 0 & 1 & 3 & 75 \\
\hline 13 & ML & 1 & 1 & 0 & 0 & 2 & 50 \\
\hline 14 & Mu.L & 1 & 1 & 0 & 0 & 2 & 50 \\
\hline 15 & NOS & 1 & 1 & 0 & 0 & 2 & 50 \\
\hline 16 & SAN & 1 & 1 & 0 & 0 & 2 & 50 \\
\hline 17 & SLL & 1 & 1 & 1 & 0 & 3 & 75 \\
\hline 18 & $S$ & 1 & 1 & 1 & 0 & 3 & 75 \\
\hline 19 & $\mathrm{VL}$ & 1 & 1 & 1 & 0 & 3 & 75 \\
\hline 20 & VA & 1 & 1 & 1 & 0 & 3 & 75 \\
\hline 21 & WAM & 1 & 1 & 0 & 0 & 2 & 50 \\
\hline 22 & YW & 1 & 1 & 0 & 0 & 2 & 50 \\
\hline 23 & YPS & 1 & 1 & 0 & 0 & 2 & 50 \\
\hline 24 & YF & 1 & 1 & 0 & 0 & 2 & 50 \\
\hline 25 & EDK & 1 & 1 & 0 & 0 & 2 & 50 \\
\hline 26 & RDT & 1 & 1 & 0 & 0 & 2 & 50 \\
\hline 27 & $\mathrm{~N}$ & 1 & 1 & 0 & 0 & 2 & 50 \\
\hline 28 & AR & 1 & 1 & 0 & 0 & 2 & 50 \\
\hline 29 & AI & 1 & 1 & 0 & 0 & 2 & 50 \\
\hline 30 & AAN & 1 & 1 & 0 & 0 & 2 & 50 \\
\hline 31 & ANNN & 1 & 1 & 1 & 0 & 3 & 75 \\
\hline 32 & $\mathrm{CM}$ & 1 & 1 & 1 & 0 & 3 & 75 \\
\hline 33 & DEIH & 1 & 1 & 0 & 1 & 3 & 75 \\
\hline 34 & DEE & 1 & 1 & 0 & 1 & 3 & 75 \\
\hline 35 & FNQ & 1 & 1 & 0 & 1 & 3 & 75 \\
\hline 36 & IRT & 1 & 1 & 0 & 1 & 3 & 75 \\
\hline 37 & MMAM & 1 & 1 & 0 & 1 & 3 & 75 \\
\hline 38 & MKK & 1 & 1 & 0 & 1 & 3 & 75 \\
\hline 39 & VK & 1 & 1 & 0 & 0 & 2 & 50 \\
\hline 40 & DRI & 1 & 1 & 0 & 0 & 2 & 50 \\
\hline 41 & IP & 1 & 1 & 0 & 0 & 2 & 50 \\
\hline 42 & LNJ & 1 & 1 & 0 & 0 & 2 & 50 \\
\hline 43 & $\mathrm{MC}$ & 1 & 1 & 1 & 0 & 3 & 75 \\
\hline 44 & NTM & 1 & 1 & 1 & 0 & 3 & 75 \\
\hline 45 & RFS & 1 & 1 & 1 & 0 & 3 & 75 \\
\hline 46 & SN & 1 & 1 & 1 & 0 & 3 & 75 \\
\hline 47 & SW & 1 & 1 & 0 & 0 & 2 & 50 \\
\hline 48 & SHSU & 1 & 1 & 0 & 0 & 2 & 50 \\
\hline 49 & SR & 1 & 1 & 0 & 0 & 2 & 50 \\
\hline 50 & FKZ & 1 & 1 & 0 & 0 & 2 & 50 \\
\hline 51 & MIA & 1 & 1 & 0 & 0 & 2 & 50 \\
\hline
\end{tabular}


Saeful, Analisis Pemahaman Bilangan Phi $(\Pi) \ldots$

\begin{tabular}{|c|c|c|c|c|c|c|c|}
\hline NO & NAMA & SOAL A & SOAL B & SOAL C & SOAL D & $\begin{array}{c}\text { JML } \\
\text { SKOR }\end{array}$ & NILAI \\
\hline 52 & MS & 1 & 1 & 0 & 0 & 2 & 50 \\
\hline 53 & NCI & 1 & 1 & 1 & 0 & 3 & 75 \\
\hline 54 & NN & 1 & 1 & 1 & 0 & 3 & 75 \\
\hline 55 & PPS & 1 & 1 & 0 & 0 & 2 & 50 \\
\hline 56 & KSSGT & 1 & 1 & 0 & 0 & 2 & 50 \\
\hline 57 & VSA & 1 & 1 & 0 & 0 & 2 & 50 \\
\hline 58 & IDA & 1 & 1 & 0 & 0 & 2 & 50 \\
\hline 59 & AS & 1 & 1 & 0 & 0 & 2 & 50 \\
\hline 60 & AIN & 1 & 1 & 0 & 0 & 2 & 50 \\
\hline 61 & CDR & 1 & 1 & 0 & 0 & 2 & 50 \\
\hline 62 & DFM & 1 & 1 & 0 & 0 & 2 & 50 \\
\hline 63 & DN & 1 & 1 & 0 & 0 & 2 & 50 \\
\hline 64 & EGA & 1 & 1 & 0 & 0 & 2 & 50 \\
\hline 65 & EMA & 1 & 1 & 0 & 0 & 2 & 50 \\
\hline 66 & FNI & 1 & 1 & 0 & 0 & 2 & 50 \\
\hline 67 & FI & 1 & 1 & 0 & 0 & 2 & 50 \\
\hline 68 & HAH & 1 & 1 & 0 & 0 & 2 & 50 \\
\hline 69 & HR & 1 & 1 & 0 & 0 & 2 & 50 \\
\hline 70 & IF & 1 & 1 & 0 & 0 & 2 & 50 \\
\hline 71 & KRB & 1 & 1 & 0 & 0 & 2 & 50 \\
\hline 72 & LK & 1 & 1 & 0 & 0 & 2 & 50 \\
\hline 73 & LN & 1 & 1 & 0 & 0 & 2 & 50 \\
\hline 74 & LKh & 1 & 1 & 0 & 0 & 2 & 50 \\
\hline 75 & MRF & 1 & 1 & 0 & 0 & 2 & 50 \\
\hline & & JUMLAH & & & 4400 \\
\hline & & & & & & 58,7 \\
\hline
\end{tabular}

Berdasarkan tabel 2 di atas, dapat dijelaskan bahwa pada soal A bertujuan mengetahui kemampuan mahasiswa dalam mengetahui asal mula phi $(\pi)$ dalam rumus keliling lingkaran mahasiwa seluruh mahasiswa menjawab soal tersebut dengan benar. Selanjutnya pada soal b bertujuan mendeskripsikan ingatan mahasiswa terhadap rumus keliling lingkaran, semua mahasiswa juga menjawab soal tersebut dengan benar. Pada soal c bertujuan mengetahui kemampuan mahasiswa dalam membedakan nilai phi $(\pi)$ dalam rumus keliling lingkaran hanya 14 mahasiswa. Pada soal $\mathrm{d}$ bertujuan mengetahui kemampuan mahasiswa dalam mencari nilai phi $(\pi)$ pada lingkaran, dengan jawaban mahasiswa yang berhasil menjawab sebanyak 12 mahasiswa

\section{PEMBAHASAN}

Berdasarkan tabel 2 Hasil tes pemahaman mahasiswa terhadap nilai phi $(\pi)$ dapat diperoleh gambaran sebagai berikut. 
Saeful, Analisis Pemahaman Bilangan Phi (П)...

\section{Perbandingan Hasil Pemahaman Tes Mahasiswa}

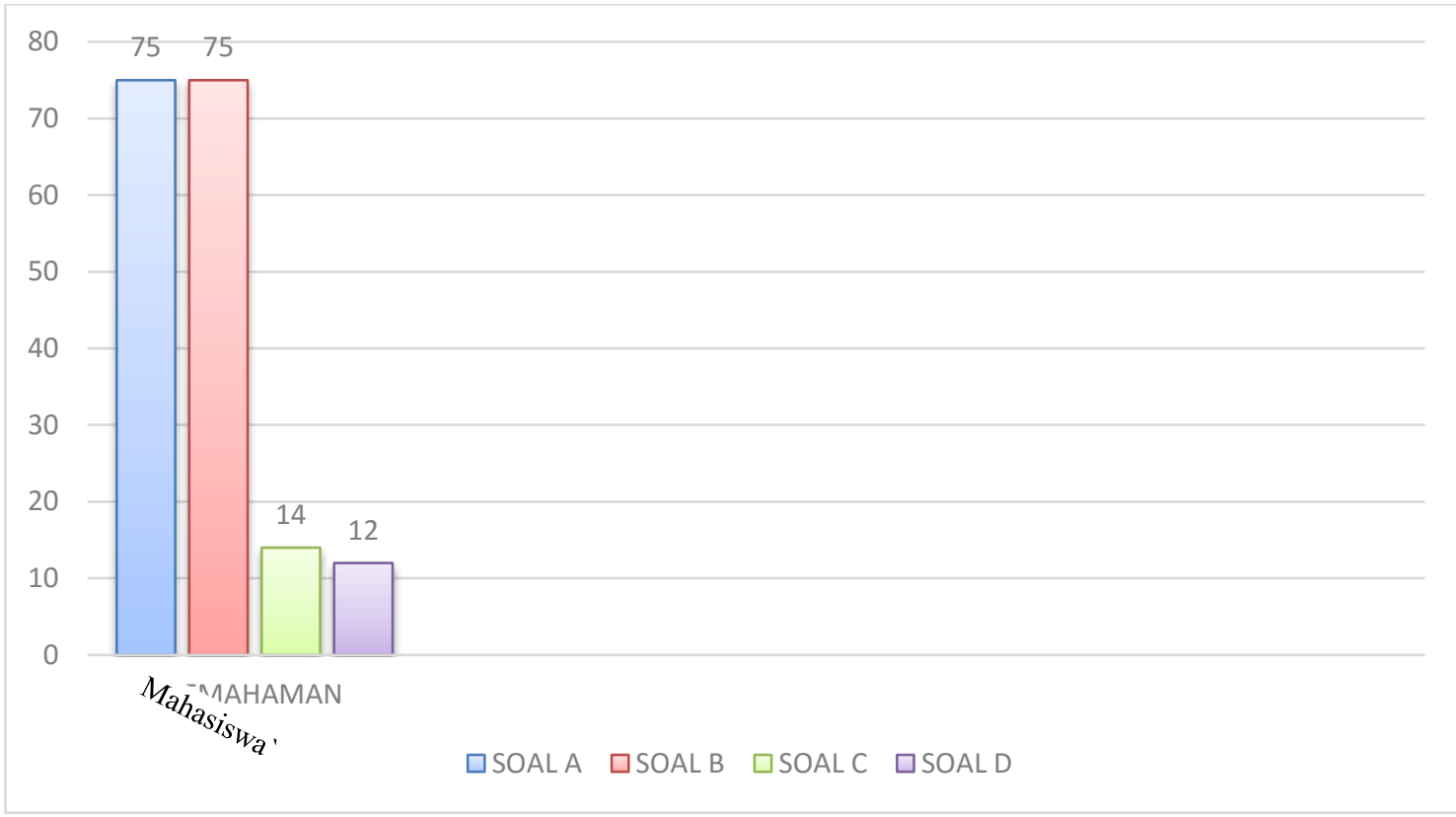

Gambar 1 Perbandingan Hasil Pemahaman Tes Mahasiswa

Sumber : tabel 2 Hasil tes pemahaman mahasiswa terhadap nilai phi $(\pi), 2019$

Gambar 1 Secara keseluruhan pemahaman mahasiswa dapat dilihat dari 4 pertanyaan yang dijawab oleh mahasiswa. Sebanyak 75 mahasiswa menjawab soal A secara benar. Soal A terkait dengan pengetahuan mahasiswa makna dari phi $(\pi)$. Selanjutnya pada soal B seluruh mahasiswa mampu menjawab pertanyaan tersebut. Sebanyak 75 mahasiswa mampu mengetahui rumus keliling lingkaran dengan baik Pada soal $\mathrm{C}$ hanya 14 mahasiswa saja yang mampu menjawab dengan benar hal ini berarti mahasiswa kesulitan memahami asal-usul nilai phi $(\pi)$ dalam rumus lingkaran. Sebanyak 61 mahaswa masih belum memahami makna nilai phi $(\pi)$ dalam rumus lingkaran. Pada soal D sebanyak 12 mahasiswa yang mampu memahami cara mencari nilai phi $(\pi)$ dalam rumus lingkaran dan sebanyak 63 masih belum mamahami cara mencari nilai phi $(\pi)$.

Berdasarkan paparan data di atas dapat diketahui bahwa pada soal A dan Soal B mahasiswa mampu memahami dengan menjawab benar dengan sebanyak 100\% mahasiswa menjawab dengan benar. Selanjutnya mahasiswa kesulitan memahami tertutama pada soal Poin $\mathrm{C}$ dan poin $\mathrm{D}$ yang terkait dengan asal mula nilai phi $(\pi)$ dan bagaimana mencari nilai phi $(\pi)$ itu sendiri. Jika diprosentasekan pada soal C, mahasiswa mampu menjawab makna nilai phi $(\pi)$ sebanyak $18,66 \%$ saja dari jumlah sampel mahasiswa. Sedangkan pada soal D, mahasiswa mampu menjawab cara menemukan nilai 
Saeful, Analisis Pemahaman Bilangan Phi (П)...

phi $(\pi)$ sebanyak $16 \%$ mahasiswa. Hal tersebut terjadi karena mahasiswa selama ini hanya memahami bahwa nilai phi $(\pi)$ adalah 3,14 dan 22/7 tanpa mengetahui proses terjadinya. Mahasiswa hanya mengahfal rumus saja. Karena pada pemahaman soal A dan B kebanyakan mahasiswa mampu menjawab dengan benar.

\section{Perbandingan Nilai Mahasiswa}

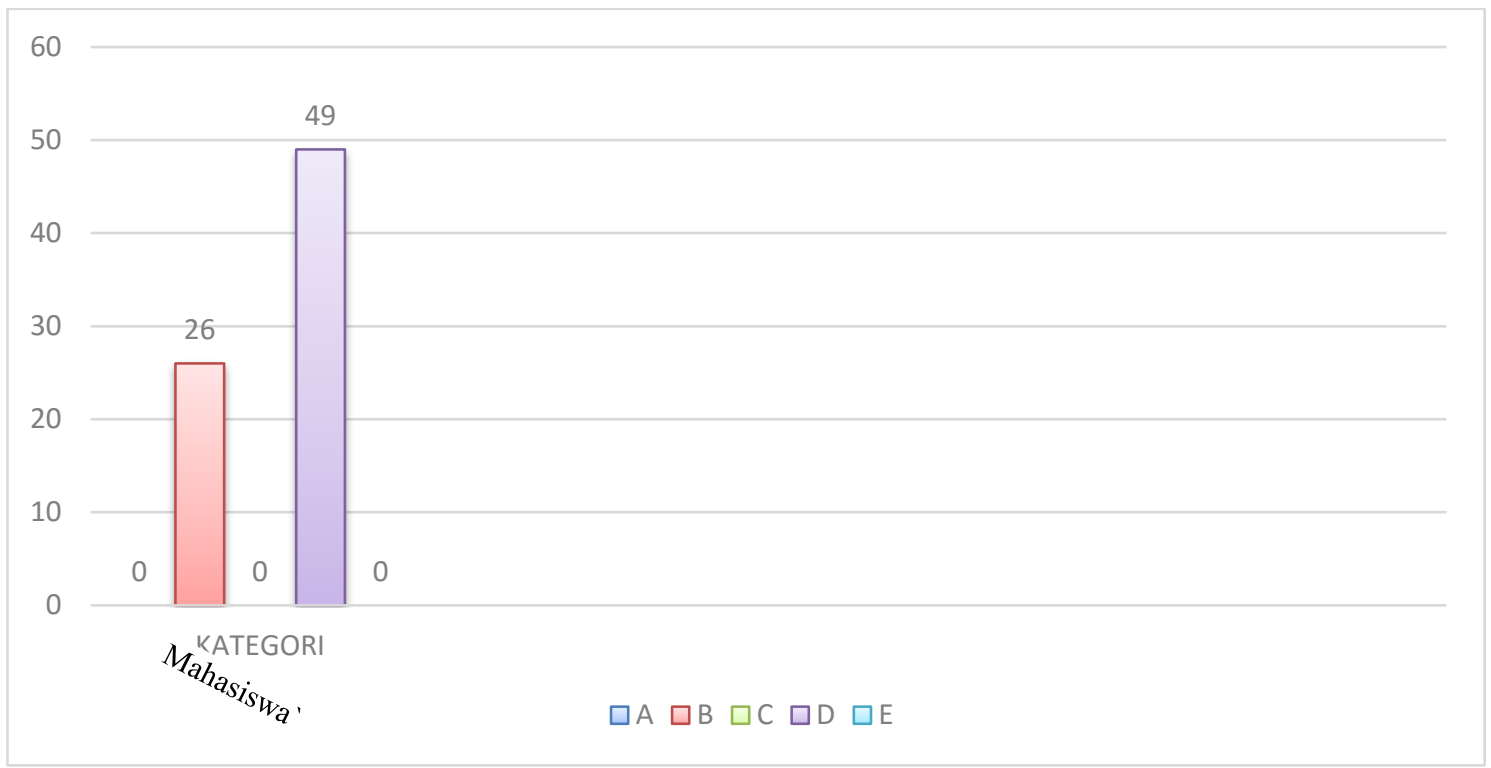

Gambar 2 Perbandingan Hasil Nilai Mahasiswa

Sumber : tabel 2 Hasil tes pemahaman mahasiswa terhadap nilai phi $(\pi)(2019)$

Pada gambar 2 dijabarkan bahwa sebanyak 26 mahasiswa memiliki kategori baik dengan nilai rata-rata 75, dengan konversi huruf B. Selanjutnya sebanyak 49 mahasiswa memiliki kategori kurang baik dengan nilai rata-rata 50 dengan konversi nilai $D$. Sedangkan nilai rata-rata semua mahasiswa diperoleh 58,7. Hal tersebut berarti secara keseluruhan mahasiswa dalam kategori kurang baik dengan konversi nilai D. Dengan demikian mahasiswa memiliki pemahaman yang tergolong masih sangat rendah.

\section{SIMPULAN}

Berdasarkan hasil analisis data dapat disimpulkan bahwa mahasiswa PGSD Unirow Tuban 2018 memiliki pemahaman yang tergolong masih sangat rendah terhadap nilai phi $(\pi)$, dengan nilai rata-rata yang diperoleh 58,7 dalam kategori kurang baik dengan konversi nilai D. Hal tersebut dikarenakan kognisi yang dimiliki mahasiswa masih sama dengan yang diperoleh ketika di Sekolah Dasar hal ini dapat dilihat dari hasil 
Saeful, Analisis Pemahaman Bilangan Phi (П)...

tes pada soal A dan B sebanyak 100\% mahasiswa menjawab dengan benar. Kurangnya konstruksi pengetahuan yang dimiliki mahasiswa dalam melakukan perubahan diri mengakibatkan mahasiswa kesulitan dalam mengungkapkan pengetahuan khususnya rumus lingkaran yang telah mereka dapat sebelumnya. Hal tesebut terlihat dari sebagian besar mahasiswa kesulitan dalam memahami, tertutama pada soal Poin $\mathrm{C}$ dan poin $\mathrm{D}$ yang terkait dengan asal mula nilai phi $(\pi)$ dan bagaimana mencari nilai phi $(\pi)$ itu sendiri. Jika diprosentasekan pada soal $\mathrm{C}$, mahasiswa mampu menjawab makna nilai phi $(\pi)$ sebanyak $18,66 \%$. Sedangkan pada soal D, mahasiswa mampu menjawab cara menemukan nilai phi $(\pi)$ sebanyak $16 \%$ mahasiswa.

\section{DAFTAR RUJUKAN}

Arifin, Zaenal. 2014. Evaluasi Pembelajaran. Bandung: PT Remaja Rosdakarya.

Arikunto, Suharsimi. 2010. Prosedur Penelitian Suatu Pendekatan Praktik. Jakarta: Rineka Cipta

Moleong, Lexy J. 2007. Metode Penelitian Kualitatif. Bandung : Remaja Rosdakarya Negeri Semarang.

Ruseffendi, E.T. 1989. Dasar-dasar matematika Modern dan Komputer untuk Guru. Bandung: Tarsito

Sugiyono. 2010. Metode Penelitian Kuantitatif, Kualitatif dan R\&D. Bandung: Afabeta Suyitno, Amin. 2005. Pendidikan Matematika I. Semarang: FMIPA Universitas 